\title{
PRESENT STATUS, POSSIBILITIES AND PERSPECTIVE OF DEVELOPMENT OF GOAT PRODUCTION IN REPUBLIC OF SERBIA
}

\author{
M. Žujović ${ }^{1}$, N. Memiší ${ }^{2}$, S. Ivanović ${ }^{3}$ \\ ${ }^{1}$ Institute for Animal Husbandry, Autoput 16, P. Box 23, 11080 Belgrade-Zemun, Republic of Serbia \\ ${ }^{2}$ AD Mlekara, Tolminska 10, Subotica, Republic of Serbia \\ ${ }^{3}$ Scientific Veterinary Institute, Belgrade, Republic of Serbia \\ Corresponding author: memisin@mlekara.rs \\ Invited paper
}

Abstract: The paper analyzes the state of goat production in the Republic of Serbia, with special emphasis on the general overview of conditions and problems that accompany this branch of animal husbandry with the proposed solutions and recommendations with the aim of increasing the productive capacity of the existing breeds of goats. Goat Serbia is characterized by a negative state, especially strong negative trend over the number of goats. Production of goat milk and meat past few years has stagnated at very low levels. As a small producer of these foods, our country can not meet the needs of its population in them, nor to any one market may not emerge as a serious bidder. For these reasons, imposes itself as a priority in the agricultural policy of our country, the constant application and approval of new incentives in the goat in order to create as many commodity producers of milk and meat, especially of kid meat intended for export. Serbia goat development opportunities exist and are available through the agricultural areas, where special emphasis should be placed on individual farms, their size, and to deal with the goat as the primary production in the highlands, and in some areas and the plains, where land and soil suitable for meadows and pastures. However, evaluation of the potential and benefits is very low, and the prosperity of goats farms not possible without a transformation of the wider economic and social environment.

Key words: goat breeding, production, milk, meat, goat kids

\section{Introduction}

Present status of Serbian goat breeding is not favourable since the number of goats used in production of milk and meat is relatively low and sufficient only for meeting of the demand on the domestic market. The negative trend in the number of goats has been present for over three decades and it is anticipated that it 
will continue in the future. The situation is considerably aggravated by the large number of non-commercial holdings/households with mainly older population, without any modern equipment, lack of motivation for this production, where it is difficult or impossible to organize high quality production, or make long term production plans.

\section{Goat production in the world}

Data referring to number of goats in different parts of the World is presented in Table 1, as well as their percentage in total number (FAOSTAT, 2008).

Table 1. Number of goats in the World (FAOSTAT, 2008)

\begin{tabular}{|l|c|c|}
\hline Continent & $\begin{array}{l}\text { Number of goats } \\
\text { (million) }\end{array}$ & \% of total number of goats in the world \\
\hline Asia & 514.4 & 59.7 \\
Africa & 291.1 & 33.8 \\
North America & 3.0 & 0.4 \\
Central America & 9.0 & 1.0 \\
Caribbean & 3.9 & 0.5 \\
South America & 21.4 & 2.5 \\
Europe & 18.0 & 2.1 \\
Oceania & 0.9 & 0.1 \\
\hline Total & 861.9 & \\
\hline
\end{tabular}

Based on data presented in Table 1, number of goats in the world is 861,9 million (FAOSTAT, 2008). However, there are considerable variations in regard to the distribution and number of goats in different parts of the world. Most goats are reared in Asia - 59,7 \%( China, India, Pakistan and Bangladesh has $45 \%$ of goats), followed by Africa - 33,8\% of total number of goats in the World. The least number of goats is reared in Oceania, approx. $0,1 \%$. Interesting is the fact that the number of goats has increased by $146 \%$ in regard to total number (590.1 million) recorded in year 1990. Number of goats in the world is in constant increase since 1990 by around 1 to $4 \%$ each year (Figure 1).

However, despite the fact that this branch of livestock production had the highest growth rate in last 20 years, global situation in regard to goat production in the world shows contradictory situation. On one hand, there are well organized private sectors in several countries which have clearly defined breeding and selection goals in goat production, and have constant progress in production of milk, meat and thread. On the other hand, most of the goat population is mainly used for production of milk, meat, leather or threads in developing countries but without any greater tendencies towards quantitative and qualitative improvement of production. So, milk, and primarily meat, meets the nutritional requirements of 
rural population in developing countries, especially in those regions with rapid growth of human population (Boiazoglu et al., 2005; Dubeuf et al. 2005; Devendra, 2007). This means that increase of number of goats is no indicator of positive development of productivity, but simply reflects the fact that many people living in rural regions of developing countries are trying to survive by keeping small ruminants, such as goats (Dubeuf and Boiazoglu, 2009).



Graph 1. Number of goats in the world in the period from 1990 to 2008 (FAOSTAT, 2008)

In developed countries in recent years, goat breeders have developed broad product range of high quality and clear nutritional values for broad consumer population. In addition, goat flocks have very important role in protection of the environment (control of forest fires, weed control) and social aspect (to maintain the population of certain region or territory) (Morand-Fer et al., 2004; Kastel et al, 2007).

Table 2. Increase of number of goats in the period from 1985 to $2005\left(10^{6}\right.$ animals $)$ Source: FAOSTAT (2006)

\begin{tabular}{|c|c|c|c|c|c|c|}
\hline & 2005 & & Index\% & 1985 & & Index \% \\
\hline $\begin{array}{l}\text { Europe } \\
\text { West Europe } \\
\quad \text { East Europe }\end{array}$ & & $\begin{array}{c}11.6 \\
2.8\end{array}$ & $138(2.2)$ & 12.87 & $\begin{array}{c}10.7 \\
2.2\end{array}$ & $100(2.65)$ \\
\hline $\begin{array}{l}\text { Asia } \\
\\
\text { Middle East }\end{array}$ & 519.6 & 221.1 & $184(64.2)$ & 282.4 & 149.4 & $100(58.2)$ \\
\hline $\begin{array}{ll}\text { America } & \\
& \text { North A. } \\
& \text { Central A. } \\
& \text { South A. } \\
\end{array}$ & 33.7 & $\begin{array}{c}2.5 \\
9.1 \\
22.1\end{array}$ & $104(4.2)$ & 32.1 & $\begin{array}{c}1.6 \\
11.1 \\
19.4\end{array}$ & $100(6.6)$ \\
\hline Africa & 232.9 & & $157(28.7)$ & 147.9 & & $100(30.4)$ \\
\hline Oceania & 0.87 & & $79(0.011)$ & 1.1 & & $100(0.22)$ \\
\hline Total in the world & 808.9 & & 166 & 485.1 & & 100 \\
\hline
\end{tabular}


In countries of European Union approx. $2 \%$ of world goat population is reared, but only $13,2 \%$ of milk and $2,0 \%$ of meat is produced $F A O, 2006)$. In the last 10 years (Table 2), production decreased (2,5\%), although in some countries, such as France and Spain, the number of goats even increased by approx. 3,4\% and $8,8 \%$, respectively. Of EU countries, Greece, Spain, France and Italy $(5,4 ; 2,8 ; 1,2$ and 0,9 million animals) have the largest number of goats (FAO, 2006).

Goat flocks reared in EU countries are more specialized for dairy production compared to those in developing countries, and especially in France, Greece and Spain, where annual production of goat milk is 583, 511 and 423 million litres, respectively, which makes $83 \%$ of goat milk production in EU. Of mentioned countries, only France and Spain have increased their production in the last 10 years $(23,5 \%$ and $15,8 \%)$, because of high productivity of goat breeds reared in mentioned countries (Boiazoglu et al., 2005.), and especially in Spain, as a result of improvement in the farm management and applied technologies (Kastel et al, 2003; Mena et al., 2005). The implication is that production of kid meat in EU countries has dropped in the last 10 years by $4,8 \%$, mainly in France and Spain $(12,2 \%$ and $19,4 \%)$.

\section{Goat production in Republic of Serbia}

In present conditions in Serbia, goats are mainly reared intensively, although there are some tendencies towards intensifying of this production. Goats are mainly reared in hilly-mountainous regions, less economically developed areas with modest or poor food sources. There is difference in the number of goats reared in different regions, starting from areas where they are very rare, to those where they are considerably more numerous. They are reared mainly by poor households from passive regions or those without sufficient food for cows, to use goats as animal of very modest requirements to produce valuable foodstuff to satisfy their needs. Interest of individual holdings/farms for goat rearing is constantly increasing. Goats are reared mainly on individual agricultural households, usually 1 to 2 animals, although in the field there are breeders with 20,30,50 and more goats in rearing.

There is still no keeping of records and statistics on number of goats and their production in Serbia. According to one poll (1980), in Republic of Serbia, without provinces, approx. $9 \%$ of total number of goats is reared $(55,000)$ in relation to the territory of former SFRY, and according to statistical data from 1991, approx. 245.000 goats are reared on the territory of Republic of Serbia. Number of goats in Serbia, according to the study/questionnaire carried out by the Institute for Animal husbandry, Belgrade-Zemun in 2003 was 318.000 , and the assessment based on scientific and breeding experiences is that the distribution of goats differs from region to region. So, goats are mainly reared in Niš district - 
$30.56 \%$, followed by Belgrade district - $24.57 \%$, Morava district - $17.83 \%$, Danube river district $-9.55 \%$, Raška district $-9.30 \%$, Zaječar district - 2.62\%, Vojvodina $2.35 \%$ and in other districts $-3.22 \%$, Žujović et al. (2004).

In regard to the breed structure, the least represented are goats of Alpine breed - approx. 2-3\%, White Serbian goat - 15\%, different types of crosses approx. 35\% same as goats of low land Balkan type and approx. $12 \%$ of high land Balkan type. Based on results of scientific studies on goat rearing - phenotypic and production data, generally, in Republic of Serbia (Žujović et al., 1983, 1984, 2000, 2001, 2002; Memiši, 2000) most goats represent a product of various mutual crossing of Balkan goat of low and high land type, as well as their crossing with different types of crosses with Saanen breed. Domestic white goats, especially short haired animals, are different types of crosses of Domestic White goat and Saanen goat, i.e. increase of their number in certain way caused increase of number of dairy goats on account of Domestic Balkan goats. Also, in Serbia, Saanen breed, Alpine and Fawn goat breeds, because of inbreeding, are considerably degenerated since there was no effort and work to refresh blood. In recent years, certain number of coloured goats has been imported - such as Alpine, German Spotted and Fawn goat breeds.

Production of our goats is directed towards milk-meat, but priority is milk. This relates especially on households where the production of goat milk is more acceptable than rearing of cows or sheep, even though goat milk (contrary to other types of milk) still is not regulated and protected by certain government subsidies and other incentive measures.

The last decade has brought significant changes in attitude towards goat farming, there is more interest in intensive rearing system especially in family/individual holdings/farms, however still without any comprehensive perception and organization. Increasing interest in goat rearing has led to demand for more productive goats in the intensive rearing system. However, deficit in high quality breeding females in Serbia is causing that interested producers have to start with few goats. New as well as older households/farms cannot produce more high quality breeding animals for sale, because they are increasing their flocks and working on breed improvement of the Domestic Serbian goat and Balkan breed of both types. Production of selected female breeding progeny is insignificant, as well as number of noble imported breeds - such as Alpine, German Spotted, Saanen and Fawn goat breeds. In practice, there is also the problem of identification of nutrition, housing and rearing conditions with sheep, which is not correct. Also, the perception of goat as animal of „,modest" nutrition requirements is wrong, same as comparing of their needs with those of sheep (Memiši and Bauman, 2007). Although there are lot of similarities in housing facilities and equipment, certain differences must be taken into consideration. This perception is causing negative consequences and lower production, especially in high yielding dairy goats (Memiši and Žujović 2010; Žujović et al. 2010). 
Specific properties and diversity of goat products have clearly been the reason why many countries decided to increase the profitability using high yielding goats in intensive rearing system. Experiences of countries with high goat production confirm that there are objective and realistic potentials for development of this livestock branch in our country. Therefore, it is necessary to replace the traditional, primitive rearing of goats with modern, organized system. This requires change of rearing system used so far, especially change of the breed structure and nutrition of goats. Transition to more intensive rearing system would not be too difficult, since goats are easy adaptable and adjustable to new conditions of intensive rearing (Memiši et al. 2009).

\section{Domestic goat breeds and their production abilities}

In previous period, selection was carried out on domestic and imported breeds. Goats were mainly selected and reared based on production parameters, and rarely under the supervision of breeder, and especially of selection experts. This is the reason why milk performance in domestic genotypes is very different and mainly depends on the level of provided care and nutrition. Also, this is the reason why wide variability in regard to production performance between breeds as well as within certain genotypes has been established in numerous studies (Žujović, 1988, 1993; Memiši, 2000; Žujović et al. 2006).

Balkan goat is autochthonous goat breed included in the program of protection and preservation of animal genetic resources on the territory of Serbia. From the zootechnical aspect, this breed is interesting for several reasons. It can be said that it hasn't been exposed to more serious selection efforts and pressure, so present variability allows relative fast realization of certain breeding positive results. It is also very well adapted to modest conditions of care, housing and nutrition, and its robustness can be used as one of the major functional traits in total improvement of the breed. Milk performance of the Balkan breed is relatively lower compared to noble breeds, even improved transitional breeds. According to research by Memiši (2000), milk performance of Balkan goats reared on farms located at different altitudes around Prizren, ranged from 172 to $184 \mathrm{~kg}$ in lactation of average 237 days. Somewhat higher milk performance of Balkan goat reared in semi-extensive housing conditions on farms in Southeast Serbia was established by Bogdanović et al. (2008) - approx. $378 \mathrm{~kg}$ in lactation period of 256 days. However, compared to local, primitive breeds reared in other parts of Europe or world, milk performance of Balkan goat is in expected, biological frames for this breed type. In general analysis of the potential for use of high yielding breeds as ameliorators in flocks of local, primitive breeds, Serradilla (2001) states that milk performance of autochthonous Italian and Maltese goat breeds ranged from 135 to $360 \mathrm{~kg}$, of Greek breeds from 100 to $180 \mathrm{~kg}$ and Turkish local breeds from 120 to 
$400 \mathrm{~kg}$. In order for rearing of Balkan goat to be economically sustainable and profitable, it is necessary to analyze the production results from different rearing systems, and establish future breeding goals and programs for their realization. Keeping of Balkan goat is most often associated with extensive, semi-extensive or semi-intensive rearing system, and rarely with intensive system.

Number of goats varies from year to year with moderate increase or decrease of number of animals depending on the interest of breeders. However, number of animals that are under control of field zootechnical services is decreasing every year (Report and results of the control of execution of the breeding program for year 2010 - Institute for Animal Husbandry, Belgrade Zemun).

Results of the productivity of goats according to the genotypes in individual agricultural sector are presented in Table 3.

Table 3. Average values for productivity of goats according to genotypes in 2010 on individual farms

\begin{tabular}{|c|c|c|c|c|c|c|c|c|c|}
\hline \multirow[b]{2}{*}{ Genotype } & \multirow{2}{*}{$\begin{array}{c}\text { Body mass } \\
\text { of adult } \\
\text { animals } \\
(\mathrm{kg})\end{array}$} & \multirow[b]{2}{*}{$\begin{array}{c}\text { Fertility } \\
(\%)\end{array}$} & \multirow[b]{2}{*}{$\begin{array}{c}\text { Lactation } \\
\text { (days) }\end{array}$} & \multirow[b]{2}{*}{$\begin{array}{l}\text { Milk } \\
(\mathrm{kg})\end{array}$} & \multirow[b]{2}{*}{$\begin{array}{l}\text { MF } \\
(\%)\end{array}$} & \multirow{2}{*}{$\begin{array}{c}\text { Average } \\
\text { daily yield } \\
\text { of milk } \\
(\mathrm{kg})\end{array}$} & \multicolumn{3}{|c|}{ Body mass of kids $(\mathrm{kg})$} \\
\hline & & & & & & & $\begin{array}{c}\text { At } \\
\text { birth }\end{array}$ & $\begin{array}{c}30 \\
\text { days }\end{array}$ & $\begin{array}{c}\text { Weani } \\
\text { ng }\end{array}$ \\
\hline Alpine goat & 49,92 & 1,60 & 215 & 465,18 & 4,16 & 2,16 & 2,85 & 8,88 & 18,58 \\
\hline $\begin{array}{l}\text { Serbian } \\
\text { White goat }\end{array}$ & 46,22 & 1,57 & 212 & 370,23 & 3,95 & 1,74 & 2,63 & 6,38 & 13,43 \\
\hline Balkan goat & 43,39 & 1,35 & 209 & 187,49 & 3,85 & 0,89 & 2,38 & 6,60 & 13,42 \\
\hline
\end{tabular}

Based on obtained results it was established that average values for body mass of adult goats, fertility, lactation duration, body mass of kids at birth, at the age of 30 days and at weaning, considering the rearing, nutrition and housing conditions, are at relatively satisfactory level. Great variations in production performance and traits within flocks, as well as between flocks are present. It should be pointed out that different types of Balkan goat and Serbian White goat, excluding certain number of Alpine and Saanen goats, have relatively low milk performance/yield and fertility (Memiši, 2000; Memiši et al. 2004). Milk yield is approx. 300 - $350 \mathrm{~kg}$ of milk (Memiši and Bauman, 2003; Žujović, 1988, 1993; Žujović et al. 2006), if fed properly (which most often is not the case) and around 1.5 kids per goat and partus. This production is very low. Milk yield of $650-700$ $\mathrm{kg}$ milk, (Žujović, 1993; Žujović et al., 2001), is realized by adequate application of breeding programs, nutrition and care, whereas for even higher production of $800-$ $1000 \mathrm{~kg}$ and over $1000 \mathrm{~kg}$ application of selection is necessary, which is presently not the case, therefore in the first phase focus should be on the annual production of $550-600 \mathrm{~kg}$. 
Based on productivity data according to genotype, it can be concluded that technological rearing procedures, housing and care are more or less sufficiently applied. Selection programs are realized with the minimum of continuity, so the results of implemented selection measures are modest. In Tables 4 and 5 the average values of fertility traits are presented, also body development and milk performance of different genotypes of goats over three year period (2008-2010) (Report and results of the control of execution of the breeding program for year 2010 - Institute for Animal Husbandry, Belgrade -Zemun).

Table 4. Average values of fertility traits and traits of body development of goats of different genotypes in three year period (2008-2010)

\begin{tabular}{|c|c|c|c|c|c|c|c|c|c|c|c|c|}
\hline \multirow{3}{*}{$\begin{array}{l}\text { Genotype } \\
\text { Year }\end{array}$} & \multirow{2}{*}{\multicolumn{3}{|c|}{$\begin{array}{l}\text { Body mass of adult } \\
\text { animals }(\mathrm{kg})\end{array}$}} & \multirow{2}{*}{\multicolumn{3}{|c|}{ Fertility (\%) }} & \multicolumn{6}{|c|}{ Body mass of kids (kg) } \\
\hline & & & & & & & \multicolumn{3}{|c|}{ At birth } & \multicolumn{3}{|c|}{ At weaning } \\
\hline & 08 & 09 & 10 & 08 & 09 & 10 & 08 & 09 & 10 & 08 & 09 & 10 \\
\hline Alpine goat & 50,56 & 51,76 & 49,92 & 1,76 & 1,66 & 1,60 & 2,98 & 2,83 & 2,85 & 18,97 & 19,44 & 18,58 \\
\hline $\begin{array}{l}\text { Serbian } \\
\text { White goat }\end{array}$ & 50,56 & 48,64 & 46,22 & 1,70 & 1,71 & 1,57 & 2,81 & 2,30 & 2,63 & 20,89 & 18,20 & 13,43 \\
\hline $\begin{array}{l}\text { Balkan } \\
\text { goat }\end{array}$ & 47,10 & 45,71 & 43,39 & 1,25 & 1,52 & 1,35 & 2,82 & 2,55 & 2,38 & 15,29 & 14,55 & 13,42 \\
\hline
\end{tabular}

Table 5. Average values of milk performance traits and traits of body development of goats of different genotypes in three year period (2008-2010)

\begin{tabular}{|l|c|c|c|c|c|c|c|c|c|c|c|c|}
\hline Year & \multicolumn{3}{|c|}{$\begin{array}{c}\text { Duration of } \\
\text { lactation } \\
\text { (days) }\end{array}$} & \multicolumn{3}{|c|}{$\begin{array}{c}\text { Quantity of milk in } \\
\text { lactation } \\
\text { (kg) }\end{array}$} & \multicolumn{3}{|c|}{$\begin{array}{c}\text { Average daily milk } \\
\text { yield (kg) }\end{array}$} & \multicolumn{4}{c|}{$\begin{array}{c}\text { MF } \\
(\%)\end{array}$} \\
\hline Alpine goat & 08 & 09 & 10 & 08 & 09 & 10 & 08 & 09 & 10 & 08 & 09 & 10 \\
\hline $\begin{array}{l}\text { Serbian } \\
\text { White goat }\end{array}$ & 222 & 187 & 215 & 489,52 & 498,59 & 465,18 & 2,20 & 2,66 & 2,16 & 3,87 & 3,78 & 4,16 \\
\hline $\begin{array}{l}\text { Balkan } \\
\text { goat }\end{array}$ & 193 & 191 & 212 & 399,52 & 356,68 & 370,23 & 2,07 & 1,87 & 1,74 & 3,92 & 3,70 & 3,95 \\
\hline $\begin{array}{l}\text { Balkan } \\
\text { goat }\end{array}$ & 192 & 206 & 209 & 345,17 & 254,66 & 187,49 & 1,80 & 1,24 & 0,89 & 3,90 & 3,86 & 3,85 \\
\hline
\end{tabular}

Based on presented average values for milk performance of certain goat genotypes over three year period it can be concluded that their production is within expectations in regard to fertility traits and milk performance.

With the increase of number of goats, research aimed at increase of yield and improvement of quality of kid and goat meat, were also realized. Special emphasis is on the study of the possibility of production of goat meat products (fermented sausages and dry goat carcass parts). With definition of the production 
procedure for these products, the possibility for protection of their geographical indication is considered.

\section{Direction of development of goat production and long-term measures}

In order to improve the present situation in goat production in Republic of Serbia, it is necessary to:

- Ensure proper use of existing pasture areas, main energy and protein feeds (corn, soybean meal, sunflower meal and other feeds),

- Establish satisfactory health status of animals and ensure maintaining of good health condition of animals as main pre-condition for goat production,

- Reconstruct, adapt existing facilities for goat rearing and build new ones,

- Provide adequate functioning of commodity reserves/inventory,

- Incentive measures by the government, measures of credit and monetary policy in function of increase of goat production,

- Improve the link between primary production and processing industry and trade,

- Consider processing/manufacturing procedures for goat meat products with protected geographical indication,

- Establish standards based on which the quality of product is determined and implement payment according to quality,

- Treat all forms of production in all segments equally.

Fulfilment of above mentioned conditions, the existing goat population, although small and burdened with numerous problems and difficulties, could represent considerable potential of Serbia in sense of ensuring significant number of healthy, and high quality animals, i.e. safe animal products of good quality (milk, meat).

Quantity of mentioned products could exceed the demand of the domestic population and so considerable surplus could be realized, intended for export. In all of this, specific traits of goat production would have to be respected and level of crisis in which goat production is at this point.

\section{Role of the government}

Development of goat production for the purpose of production of milk, meat and hide for the market starts practically from the minimum number of goats, considerable natural resources and favourable signals on the market and sources of financial means. Since there aren't any commodity producers, this initial and developmental role of the government is necessary. Engagement and support of the government are necessary in the field of agriculture and livestock production, as 
well as widely in the macro economical policy. In the field of agriculture and goat production, the support of government is needed in: fertility,

- Organization of land surfaces/landscaping and improvement of the soil

- Protection of the soil from pollution and contamination,

- Studies and programs of development of goat production,

- Means for development of necessary infrastructure (genetic centres),

- Ensuring favourable credits for facilities and equipment, forming of main flock, facilities for processing of milk and current production, animals,

- Subsidies for production and use of genetically superior breeding

- Ensuring means for interventions in the event of market disruptions,

- Support for expert training for producers, expert agricultural services and research in goat breeding,

- Adopting regulations on protection of products with geographical indication, intellectual property, incentives for export of goat cheeses, meat and hides.

More broadly the role of government is in:

- Creation of favourable macro-economic environment,

- Support for development of operations and activities with comparable advantages (significant resources, export possibilities, etc.),

- Environment protection,

- Support for ownership transformation,

- Adoption of regulations and standards on production, quality and trade of products harmonized with international criteria.

\section{Conclusion}

Goat production in Serbia is characterized by rather unfavourable condition, especially expressed through negative trend in number of goats. Production of goat milk and meat has been stagnating in the last several years. As rather small producer of these foodstuffs, our country cannot meet the demand of own population, or can it appear on any market as serious supplier of these products. In order to use the increasing interest of producers - individual farmers for goat breeding, and possibility to direct it towards commodity production, the proper guidance of this process is needed. This is the reason why goat production should be priority in the agricultural policy of Serbia, with application and granting 
of new incentive measures. Objective is forming of as many as possible commodity producers of milk and meat, especially kid meat for export.

Based on data on production performance of domestic goat genotypes in different rearing conditions, it can be concluded that enough phenotypic variability is contained in these traits for successful selection. Nature of the variability of production traits indicates that they are not only under the influence of biological characteristics of the breed, but also under influence of breeding or zootechnical conditions. This further indicates the conclusion that it is necessary to work simultaneously on the genetic improvement of domestic goat genotypes, and on continuous improvement of nutrition, housing and care in goat rearing. In this way proper expression of the genetic potential of breeds will be ensured. Also, before beginning of systematic and organized selection work, it is necessary to determine breeding goals and programs, as this is the only way to adequately improve production performance and potentials of goat breeds in Serbia.

\title{
Acknowledgment
}

Research was financed by the Ministry of Education and Science, Republic of Serbia, project TR-31053.

\section{Stanje, mogućnosti i perspektive razvoja kozarstva u Republici Srbiji}

\author{
M. Žujović, N. Memiši, S. Ivanović
}

\section{Rezime}

U radu je analizirano stanje kozarske proizvodnje u Republici Srbiji, sa posebnim osvrtom na opšti pregled uslova, kao i probleme koji prate ovu granu stočarstva sa predloženim rešenjima i preporukama, a sve u cilju povećanja proizvodnih sposobnosti postojećih rasa koza. Kozarstvo Srbije karakteriše nepovoljno stanje, posebno izraženo preko negativnog trenda broja koza. Proizvodnja kozijeg mleka i mesa poslednjih nekoliko godina stagnira i na niskom je nivou. Kao mali proizvođač ovih namirnica, naša zemlja ne može zadovoljiti ni potrebe sopstvenog stanovništva u njima, niti se na evropskom tržištu može pojaviti kao ozbiljan proizvođač. Zato se nameće prioritet u agrarnoj politici naše zemlje, stalna primena i odobravanje novih podsticajnih mera u kozarstvu u cilju stvaranja što većeg broja robnih proizvođača mleka i mesa, posebno jarećeg mesa koje može biti namenjeno izvozu. Razvojne mogućnosti kozarstva Srbije postoje i ogledaju se kroz raspoložive poljoprivredne površine. Poseban naglasak treba 
staviti na individualna gazdinstva, njihovu veličinu. Primarnu kozarsku proizvodnju treba razvijati tamo gde je bonitet zemljišta odgovarajući samo za livade i pašnjake. Međutima, valorizacija tih potencijala i prednosti je veoma niska, a prosperitet kozarskih gazdinstava nije moguć bez transformacije šireg privrednog i društvenog okruženja.

\section{References}

BOYAZOGLU J., HATZIMINAOGLOU Y., MORAND-FEHR P. (2005): The role of the goat in the society: past present and perspective for the future. Small Rumin. Res., 60, 1-2, 13-23.

CASTEL J.M., MENA Y., DELGRADO-PERTINEZ M., CAMUNEZ J., BASULTO J., CARAVACA F., GUZMAN-GUERRERO J.L., ALCALDE M.J. (2003): Characterization of semi-extensive goat production systems in southern Spain. Small Rumin. Res. 47, 133-143.

CASTEL J.M., MENA Y., RUIZ F.A. (2007): El sector caprino y su contribución al desarrollo rural (The goat sector and its contribution to rural development). In: Agricultura Familiar en Espãna. Ed. Fundación Estudios Rurales, Madrid, pp. 246-257.

DEVENDRA C. (2007): Perspectives on animal production systems in Asia. Livest. Sci., 106, 1-18.

DUBEUF J.-P., MORAND-FEHR P., RUBINO R. (2004): Situation, changes and future of goat industry around the world. Small Rumin. Res., 51, 165-173.

DUBEUF J.-P., BOYAZOGLU J. (2009): An international panorama of goat selection and breeds. Livestock Science, 120, 225-231

FAOSTAT, 2006. http://faostat.fao.org/site/409/default.aspx.

FAOSTAT (2008): http://faostat.fao.org/default.asp

MORAND-FEHR P., BOUTONNET J.P., DEVENDRA C., DUBEUF J.P., HAENLEIN G.F.W., HOLST P., MOWLEM L., CAPOTE J. (2004): Strategy for goat farming in the 21st century. Small Rumin. Res., 51, 175-183.

MEMIŠI N. (2000): Kvantitativna analiza telesne razvijenosti i proizvodnih osobina domaće balkanske koze. Doktorska disertacija, Poljoprivredni fakultet, Beograd-Zemun, 1-168

MEMIŠI N., BAUMAN F. (2003): Domaće rase koza. Poljoprivredne aktuelnosti, 5-6, 41-56.

MEMIŠI N., BAUMAN F., STOJANOVIĆ S., PAVLOV B., JOVANOVIĆ S. (2004): Production characteristics of domestic Balkan goats. Animal Genetic Resources Information, 35, 87-94.

MEMIŠI, N., FRIDA BAUMAN (2007): Ishrana koza. Monografija, Admiralbook, Beograd.

MEMIŠI N., LEVIĆ J., ĐORĐEVIĆ N. (2009): New recommendations and contemporary achievements in preparing feeds for goats feeding. XIII International Feed Technology Symposium.October 2009 Novi Sad, 153-163. 
MEMIŠI N., ŽUJOVIĆ M. (2010): Specific nutrition of goats in production cycle on the basis of body condition scoring. XIV International Feed Technology Symposium. October 2010, Novi Sad, 360-366.

MENA Y., CASTEL J.M., CARAVACA F.P., GUZMAN J.L., GONZALES P. (2005): Situación actual, evolución y diagnóstico de los sistemas semiextensivos de producción caprina en Andalucía Centro-Occidental (Present status, evolution and diagnoses of the semi-extensive goat production systems in Central-Western Andalusia). Consejería de Agricultura y Pesca, Junta de Andalucía, Seville, 222.

SERRADILLA J.M. (2001): Use of high yielding goat breeds for milk production. Livestock Production Science, 71, 59-73.

ŽUJOVIĆ M., JOSIPOVIĆ S. (1983): Uticaj telesne mase jaradi pred klanje na prinos i kvalitet mesa. VII jugoslovensko savetovanje »Kvalitet mesa i standardizacija«, Bled. Zbornik referata, 319-332.

ŽUJOVIĆ M., JOSIPOVIČ S., ĆERANIĆ V. (1984): Značaj i osobine jarećeg mesa. VII jugoslovensko savetovanje, Banja Koviljača. Savremena poljoprivreda, 299, 65-67.

ŽUJOVIĆ M. (1988): Oplemenjivanje populacije koza gajenih na farmi »Bačevsko polje« u Dimitrovgradu. Magistarski rad. Poljoprivredni fakultet, Beograd-Zemun, $1-174$.

ŽUJOVIĆ M. (1993): Proizvodnja i osobine mleka domaće bele koze. Doktorska disertacija. Poljoprivredni fakultet, Novi Sad. 1-150.

ŽUJOVIĆ M., JOSIPOVIĆ S., GLUHOVIĆ M., STRSOGLAVEC S., TOMAŠEVIĆ D. (2000): Telesna masa jaradi domaće bele koze pred klanje kao faktor prinosa i kvaliteta mesa. Journal of Scientific Agricultural Research »Arhiv za poljoprivredne nauke, 61, 213, 113-121.

ŽUJOVIĆ M., PETROVIĆ P.M., DJORDJEVIĆ-MILOŠEVIĆ S., GLUHOVIĆ M., STRSOGLAVEC S. (2001): Perspektiva ovčarskih i kozarskih domaćinstava u novom milenijumu. Savremena poljoprivreda, 50, 3-4, 337-341.

ŽUJOVIĆ M., PETROVIĆ P.M., TOMIĆ Z., CMILJANIĆ R., TOMAŠEVIĆ D., STRSOGLAVEC S., MEMIŠI,N. (2002): Uticaj ranog odlučivanja jaradiblizanaca na njihov razvoj i proizvodnju mleka i mesa. Biotechnology in Animal Husbandry, 18, 5-6, 81-85.

ŽUJOVIĆ M., TOMIĆ Z., JOSIPOVIĆ S., NEŠIĆ Z., ĆINKULOV M., PIHLER I. (2004): Stanje i mogućnosti kozarske proizvodnje. Acta agriculturae Serbica. Proceeding of 10th National Symposium on Forage Crops, IX, 17, 33-41.

ŽUJOVIĆ M., TOMIĆ Z., PETROVIĆ M.P., RUŽIĆ MUSLIĆ D., STOJANOVIĆ LJ. (2006). Kvalitet mleka srpske bele koze u prvoj laktaciji. Biotechnology in Animal Husbandry, 22, 5-6, 63-69.

ŽUJOVIĆ M., MEMIŠI, N., TOMIĆ Z. (2010): Systems and economy use grazing in nutrition of goats. XIV International Feed Technology Symposium. October 2010 Novi Sad, 352-359. 